\title{
MA·ODS 合金のスキッドレールの開発
}

附田賢 治* 飯久保知人 2 ) 磯 部 晋 3 ) 岩丸正明*) 清水成人吕

\section{1. は じめに}

鋼片加熱炉内のスラブやビレット等の被加熱材は，それ らを支持，搬送するスキッドレールとの接触により，スキ ッドマークと呼ばれる低温部が発生し, 次工程の压延にお いて，その部分に割れを生じさせたり，圧延寸法精度を悪 化させる原因となっている。スキッドマークを低減するた め, スキッドレールの高さは増加する傾向にある。 また操 業の効率化や品質向上を目的とし加熱温度が上昇傾向にあ り，1623K におよぶ場合もある。従来スキッドレールに は，固溶強化型耐熱鋳造合金が使用されているが，上記の ニーズに対応するには高温強度並びに耐酸化性が既に限界 に達している。このような背影から，超高温に耐えられる 材料として, 融点に近い温度まで十分な強度を保持し，し かも耐酸化性に優れた MA·ODS (Mechanically Alloyed Oxide Dispersion Stengthened) 合金のスキッドレールヘ の実用化に関する研究を推進した。そその結果，世界で初め てMA·ODS 合金スキッドレールの量産を可能にした. MA·ODS 合金は既に軍用ジェットェンジンの静翼に実用 化されている(1)が，民需での実用化は初めてである。

\section{2. 開発の経過}

\section{（1） MA·ODS 合金の選定}

スキッドレールの変形および損耗は主に圧縮クリープと 酸化によってもたらされる。また腐食損傷は燃焼ガス䨌囲 気中で起こる. そこで材料の選定は各 MA.ODS 合金の特
性を考慮して行った．表 1 亿候補となる MA·ODS 合金と 現有材である固溶強化型合金の化学組成および融点を示 す。図 1 $^{(2)}$ に MA758 の熱間押出材の $1623 \mathrm{~K}, 49 \mathrm{MPa}$ の 条件での熱間押出方向 $(L)$ とそれに垂直な方向 $(T)$ のクリ 一プ曲線を示す. $1623 \mathrm{~K}$ は $0.98 T m(T m$ : 固相線温度 $)$

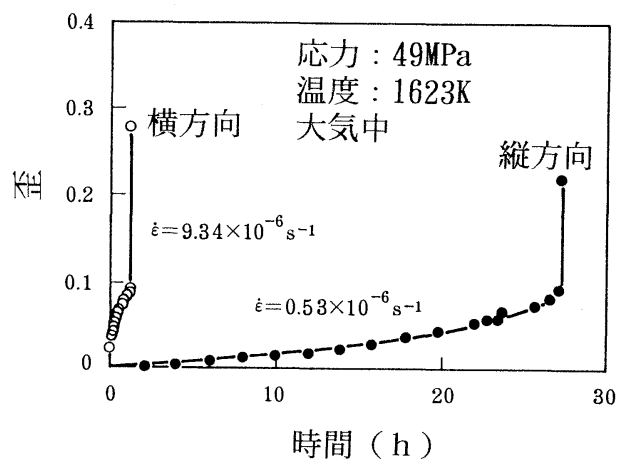

図 1 MA758 の圧縮クリープ曲線.

表 2 MA·ODS 合金および固溶強化型耐熱鋳鋼の圧 縮定常クリープ歪速度の構成方程式.

\begin{tabular}{c|c}
\hline \hline 合金 & 構成方程式 \\
\hline MA758 & $\dot{\varepsilon}=2.053 \times 10^{8} \sigma^{2.46} \exp (-133.0 / R T)$ \\
\hline MA754 & $\dot{\varepsilon}=1.276 \times 10^{10} \sigma^{1.99} \exp (-144.1 / R T)$ \\
\hline MA956 & $\dot{\varepsilon}=1.264 \times 10^{2} \sigma^{3.59} \exp (-99.8 / R T)$ \\
\hline TH101 & $\dot{\varepsilon}=2.207 \times 10^{7} \sigma^{2.19} \exp (-106.0 / R T)$ \\
\hline \multicolumn{2}{c}{$\left[\mathrm{s}^{-1}\right], \sigma[\mathrm{MPa}], R=1.986 \times 10^{-3}\left[\mathrm{kcal} \cdot \mathrm{mol}^{-1} \cdot \mathrm{K}^{-1}\right], T[\mathrm{~K}]$}
\end{tabular}

表 1 MA·ODS 合金および固溶強化型耐熱鋳鋼の化学成分 $(w t \%)$ と融点 $(\mathrm{K})$.

\begin{tabular}{c|c|c|c|c|c|c|c|c|c|c|c}
\hline \hline 合金 & $\mathrm{C}$ & $\mathrm{Ni}$ & $\mathrm{Cr}$ & $\mathrm{W}$ & $\mathrm{Co}$ & $\mathrm{Fe}$ & $\mathrm{Ti}$ & $\mathrm{Al}$ & $\mathrm{Y}_{2} \mathrm{O}_{3}$ & Solidus & Liquidus \\
\hline MA758 & 0.05 & Bal. & 29.32 & - & - & 0.67 & 0.47 & 0.25 & 0.60 & 1646 & 1672 \\
\hline MA754 & 0.05 & Bal. & 19.55 & - & - & 0.33 & 0.46 & 0.33 & 0.57 & 1685 & 1713 \\
\hline MA956 & 0.01 & 0.06 & 19.88 & - & - & Bal. & 0.38 & 4.52 & 0.62 & 1776 & 1794 \\
\hline TH101 & 0.13 & 21.46 & 31.32 & 2.07 & 22.94 & $(19.9)$ & - & - & - & 1628 & 1659 \\
\hline
\end{tabular}

* 大同特殊鋼株式会社

研究開発本部特殊鋼研究所：1)研究員 2) 室長 3) 所長

4) 東京技術サービス部次長 5) 知多工場係員

Development of MA.ODS Alloy Skid Rails; Kenji Tsukuta, Tomohito Iikubo, Susumu Isobe, Masaaki Iwamaru, Narito Shimizu (Daido Steel Corporation) 1992年 1 月 31 日受理
と, 融点直下の温度でありながらも遷移, 定常, 加速の 3 段階を有する典型的なクリープ曲線を示す。 また， $L$ 方 向のクリープ速度は $T$ 方向の約 $1 / 17$ 々さく, クリープ 強度の異方性が大さい. 表 2 に圧縮クリープ試験データか ら求めた定常クリープ速度の構成方程式 (2)を示す. 構成方 程式では歪速度が応力と温度の関数で表されている. 


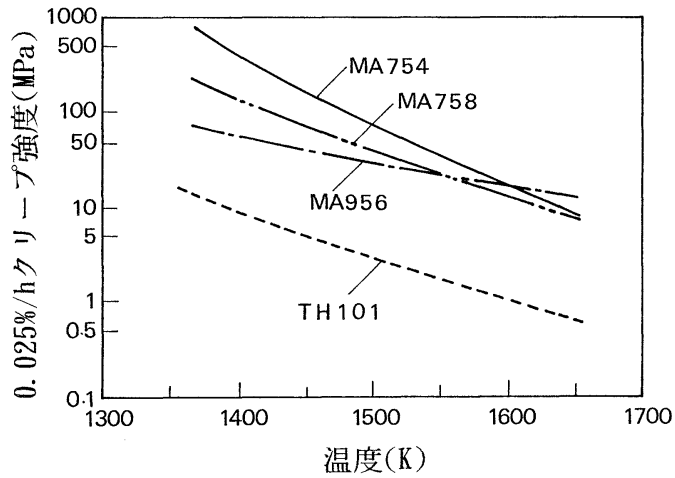

図 2 MA·ODS 合金および固溶強化型耐熱鋳鋼の高 温圧縮クリープ強度。

図 2(2) ここれらの式から $0.025 \% / h$ の歪速度を与える応力 を各温度について求めた結果を示すＭA·ODS 合金は $1623 \mathrm{~K}$ に至る広い温度範囲において, 現有材である TH101よりも12倍以上大きいクリープ強度を有してい る.

大気中, $1588 \mathrm{~K}$ で等温加熱を行い, 熱天秤により酸化 増量を求める試験を MA758 と TH101について行った結 果を図 $3^{(2)}$ に示す. MA758 は TH101よりも小さい放物 線酸化速度定数を有し，またブレークアウェイまでの潜伏 期間が長く，耐酸化性に優れている。図 $4^{(2)}$ に大気中, $1143 \mathrm{~K}$ で50 時間，腐食灰 $5.3 \mathrm{C}-52.6 \mathrm{CaSo}_{4}-31.6 \mathrm{BaSO}_{4}$ -

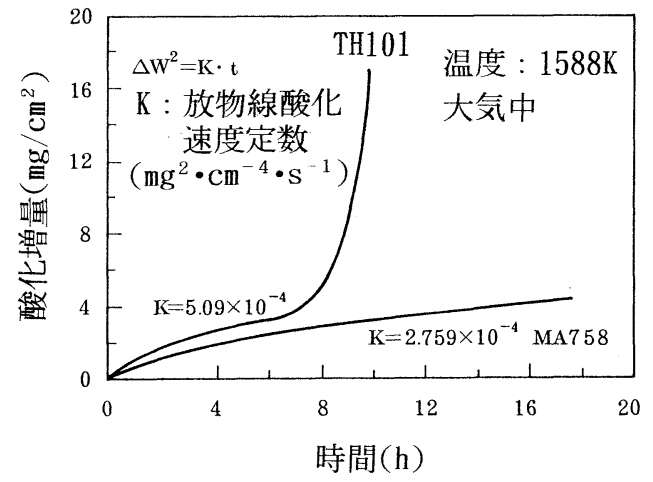

図3 $1588 \mathrm{~K}$, 静止大気中におけるMA758 と TH101 の酸化増量曲線.

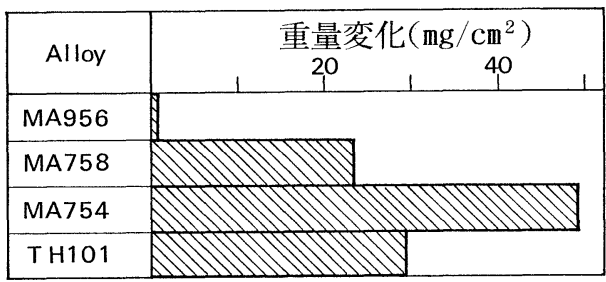

$5.3 \mathrm{C}-52.6 \mathrm{CaSO}_{4}-31.6 \mathrm{BaSO}_{4}-10.5 \mathrm{Na}_{2} \mathrm{SO}_{4}[\mathrm{wt} \%]$ $4.1 \mathrm{~cm}^{2}$ T. P. $/ 1143 \mathrm{~K} / 50 \mathrm{~h} /$ in Air

図 4 MA·ODS 合金および固溶強化型耐熱鋳鋼の高 温硫化腐食試験後の重量変化.
$10.5 \mathrm{Na}_{2} \mathrm{SO}_{4}(\mathrm{wt} \%)$ 中で行った高温硫化腐食試験における 腐食減量を示す.MA754 は最も腐食量が多いのに対し, MA956 は無視できる程に少ない。

$\mathrm{MA} \cdot \mathrm{ODS}$ 合金は高温クリープ強度は $\mathrm{Ni}$ 基と $\mathrm{Fe}$ 基でほ ぼ同等であるが，耐高温硫化腐食性は $\mathrm{Fe}$ 基の方が $\mathrm{Ni}$ 基 よりも優れている。したがって，硫黄を含有する重油を燃 料とする加熱炉には $\mathrm{Fe}$ 基の MA956 が適しており，コー クス炉ガスのような低硫黄の燃料には $\mathrm{Ni}$ 基が適当であ る.

\section{（2）スキッドレール用 MA·ODS 合金の製造}

$\mathrm{MA}$ 粉の固化は一般的に熱間押出で行い，その後熱間 圧延により所望の形状に加工する，スキッドレールの場合 は比較的大きな断面のビレットが必要であるため, MA 粉をHIPで固化し，その後熱間圧延によりビレットに加 工した. その後, $1300^{\circ} \mathrm{C}$ 以上の温度に加熱し, 2 次再結晶 を起こさせ，加工方向に伸長した高アスペクト比の粗大な 結晶粒を有する組織とした。

(3） MA·ODS 合金と鋳造材とのハイブリッド・スキッ ドレール

上記の工程で製造したビレットは切断され，図 5 に示す スキッドレールの形状に機械加工される.この際, クリー プ強度が大きい $L$ 方向(熱間圧延方向)がスキッドレール の高さ方向になるよら加工する. スキッドレールは図 5 に示すよらに, 水冷スキッドパイプの上に取り付けられる ため，下部は温度が低い。したがって，下部には高価で高 性能な MA·ODS 合金を使用するには及ばず，耐熱鋳鋼製 のサドルスキッドを取り付け，その上に MA·ODS 合金を はめ込むハイブリッド構造とした．このことにより，大幅 に製造コストを低減することがでさた。図 6 に量産したハ イブリッド・スキッドレールの外観を示す.

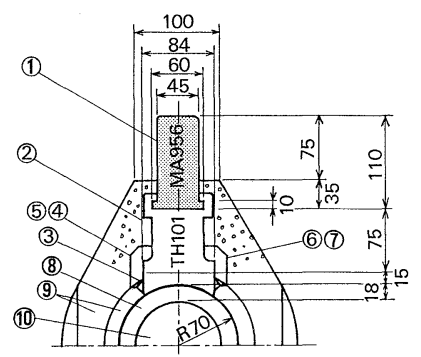

\begin{tabular}{|c|c|c|}
\hline NO. & 各部名称 & 材 質 \\
\hline 1 & スキッドレイル & MA 956 \\
\hline 2 & サドルスキッド & TH 101 \\
\hline 3 & サドル & 炭素鋼 \\
\hline $4 \sim 7$ & ストッパー & 304 S. S. \\
\hline 8 & スキッドパイプ & 炭素鋼 \\
\hline 9 & \multicolumn{2}{|c|}{ 耐火物 } \\
\hline 10 & \multicolumn{2}{|c|}{ 冷却水 } \\
\hline
\end{tabular}

図 5 MA·ODS 合金ハイブリッド・スキッドレイル の概略図. 


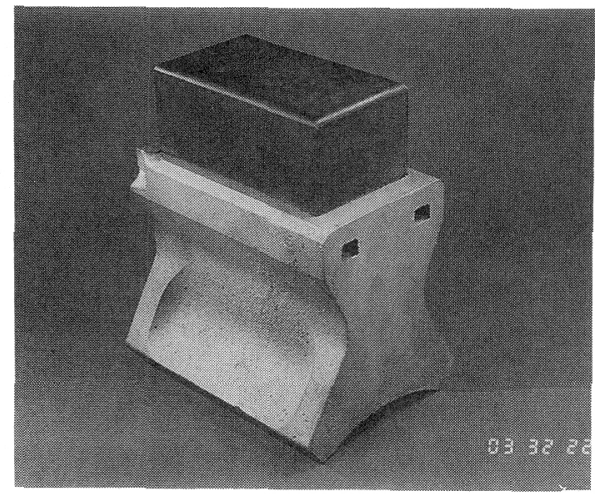

図 6 MA·ODS 合金ハイブリッド・スキッドレイル 製品例.

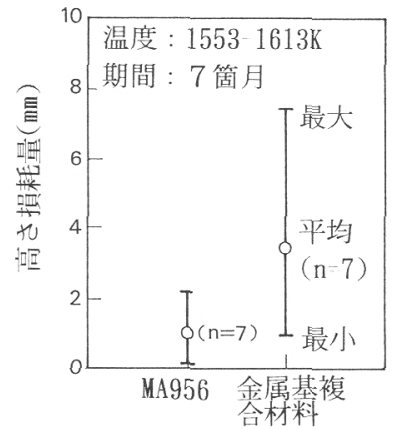

図 7 重油燃焼雲囲気加熱炉で 7 箇月使用したスキ ッドレイルの高さ損耗量.

\section{MA·ODS 合金スキッドレールの性能}

MA956 ハイブリッド・スキッドレールは大同特殊鋼(侏) 知多工場の新圧延加熱炉の均熱帯に大量採用され，加熱炉 は1990年 1 月から操業に入っている。炉内温度は 1553 K から $1613 \mathrm{~K}$ に括よび，然料は 0.16 wt \% 硫黄を含も。 ス キッドレールの高さはスキッドマークを大幅に低減するた め世界最高の $200 \mathrm{~mm}$ とした。図 7 に使用開始 7 箇月後 の高さ方向の損耗量を同じ加熱炉内の同一部分に設置した 金属基複合材料との比較で示す.MA956の損耗量は平均 で約 $1 \mathrm{~mm}$ であり，金属基複合材料の約30\%と少なかっ た．図 8 にMA956 スキッドレールの 7 箇月使用後の外観 を示すが，変形は臣とんど認められない。図 9 に本加熱炉 で加熱され，抽出されたビレットの表面温度分布をウォ一 キングハース式加熱炉で加熱されたものと比較して示すす. ビレット内の最高温度と最低温度の差,すなわらスキッド マークは $200 \mathrm{~mm}$ 高さの MA·ODS 合金を使用すること により $18 \mathrm{~K}$ とウォーキングハース式に比べ, $38 \mathrm{~K}$ む低 減された。通常，スキッドレール高さは約 $150 \mathrm{~mm}$ で, スキッドマークは約 $35 \mathrm{~K}$ であり，スキッドレールの 200 $\mathrm{mm}$ 化により，より均一な加熱が可能となり，圧延材の品 質および寸法精度を一層向上させることができた。

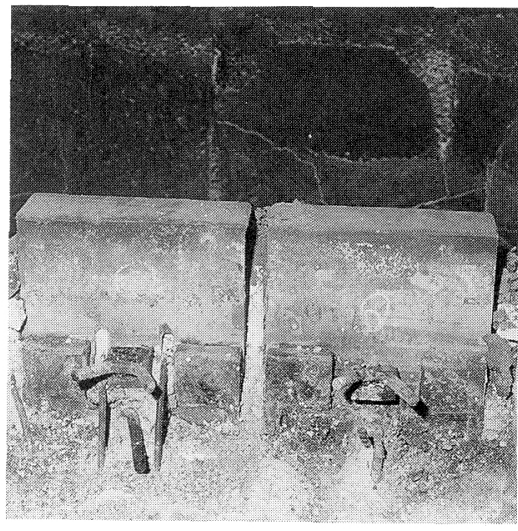

図8 重油燃焼雾囲気加熱炉で7箇月使用した MA·ODS 合金ハイブリッド・スキッドレイル 外観写真.

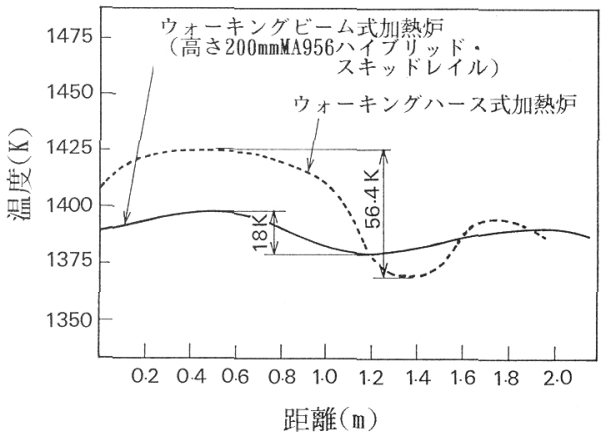

図 9 加熱されたビレット表面の長手方向の温度分 布.

\section{4. 製 造 実 績}

この MA·ODS 合金スキッドレールは平成 1 年 9 月か ら量産を開始している. 今後さらに加熱炉操業の効率化, 省エネルギー，品質向上を目的として，本合金スキッドレ 一ルの普及が期待される。

\section{5. 特許}

MA·ODS 合金，その製造技術，スキッドレールの構造 等に関して，国内および米国を初め子する諸外国に特許を 出願している。

\section{文献}

(1) R. K. Wilson, F. L. Perry: Ind. Heat., 51[5], (1984), 27.

( 2 ) K. Tsukuta, T. Iikubo and S. Isobe: "Application of Mechanically Alloyed Ni-and Fe-base Alloys to Skid Rail for Walking-Beam-Type Reheating Furnaces", Published in Structural Applications of Mechanical Alloying Proceedings of an ASM International Conference, Myrtle Beach, South Carolina, 27-29 March (1990), 99. 